\title{
Histo-bacteriological Investigation on Borderline Tuberculoid Leprosy
}

\author{
Tiesheng WANG, Khalid Iqbal BUTT, Yumi MAEDA \\ Kunio KAWATSU, Shinzo IZUMI \\ (National Institute for Leprosy Research, Tokyo)
}

(Received for publication: December 17, 1991)

Key words : Paucibacillary leprosy, Acid-fast bacilli, Serial sections, Nerve demonstration

Since 1982, the classification of leprosy based on bacterial load has been adopted world-wide for the purpose of multidrug therapy programme. According to it, the disease is divided into multibacillary (MB) or paucibacillary (PB) leprosy ${ }^{(1)}$. As more and more paucibacillary leprosy cases were observed to develop relapse after completion of treatment ${ }^{(3-7)}$, paucibacillary leprosy has been limited to smearnegative indeterminate (I), polar tuberculoid (TT) and borderline tuberculoid (BT) cases ${ }^{(2)}$. Some authors noted that histological analysis can detect densities of 500 acid-fast bacilli (AFB) in tissues and histological sections offer a number of advantages over slit-skin smears ${ }^{\text {(10. }}{ }^{12)}$. Therefore, a further study on the bacteriology of tissue sections of $\mathrm{PB}$ cases seemed to be indicated. This paper examines skin biopsy specimens taken from twelve active $\mathrm{BT}$ cases, the biggest group of $\mathrm{PB}$, for the promotion of understanding on the histo-bacteriological status of PB cases.

\section{MATERIALS and METHODS}

Paraffin blocks of $10 \%$ formalin-fixed skin biopsies taken from twelve BT leprosy cases with active lesions were retrieved from the files of the National Institute for Leprosy Research, Tokyo, Japan.

The diagnosis and classification of all cases were reconfirmed by reviewing clinical records and routine tissue sections according to Ridley and Jopling ${ }^{(8)}$

$5 \mu \mathrm{m}$ thick serial sections of paraffin blocks were cut, then stained with hematoxylin-eosin ( $\mathrm{H} \& \mathrm{E}$ ) for routine histopathological examination, by Fite method for the detection of AFB, Kawatsu's silver impregnating method for the demonstration of axons of nerve fibers ${ }^{(9)}$ and $\mathrm{S}-100$ protein $\mathrm{ABC}$ technique, anti S-100 protein antibody (Dako) was at a dilution of $1: 1000$, for the immunostaining of Schwann cells in cutaneous nerve.

\section{RESULTS}

According to the results of histopathological examination, nerve damages could be divided into four groups: A. unaffected : nerve structure was almost normal ; B. non-specific inflammation : the nerves were infiltrated by lymphocytes; C. granulomatous infiltration: the nerves involved in epithelioid cell granulomas were subdivided into three types: a. nerve segments, usually located near the border of granulomas, were encompassed by many lymphocytes but the parenchyma of nerve was relatively preserved and could be easily recognized even in sections stained with $\mathrm{H} \& \mathrm{E}$; b. nerve fragments seen mostly in the center of granuloma were partly destroyed and degenerated, resembling the fragments of atrophied arrector pili muscles, but S-100 protein was positive and $/$ or a few axons appeared in serial 
sections when stained by S-100 protein ABC technique or Kawatsu's method (Fig. 1), c. nerve remnants were completely beyond recognition in $\mathrm{H} \& \mathrm{E}$ staining sections but when stained by Kawatsu's method or S-100 protein ABC technique, the remnants showed some weak positive staining in small areas (Fig. 2). D. fibrosed and/or hyalinated: neither axon nor S-100 protein can be demonstrated.

The results of bacteriological examination and the location of AFB are shown in the table.

All 12 cases were AFB positive: in 11 cases, AFB were detected in nerve bundles; in 2 cases, AFB were found in arrector pili muscles, no AFB were detected in subepidermal zone, macrophages, blood vessels and other sites.

The AFB detecting rates of cutaneous nerve bundles with histopathological changes in varying degrees were as follows: unaffected nerve bundles, $0 \%(0 / 6)$; nerve bundles with parenchymal non-specific inflammation, $100 \%(2 / 2)$; nerve segments encompassed by lymphocytes near the border of epithelioid cell granuloma, 17\% (1/6); nerve fragments within epithelioid cell granuloma, $70 \%(7 / 10)$; nerve remnants within epithelioid cell granuloma, 18\% (2/11); fibrosed nerve bundles, $100 \%(2 / 2)$.

\section{DISCUSSION}

In the present study, all active $\mathrm{BT}$ cases were $\mathrm{AFB}$ positive. As far as the methodology on detection of $\mathrm{AFB}$ from tissue sections, the possible reasons for explanation of the high detecting rate are as follows: first, we examined multi-sections of serial cutting, and thus the chance of finding AFB was increased : second, under the guidance of special stains for demonstration of nerve components, a careful searching of $\mathrm{AFB}$ in remaining nerves within granulomas was done. Additionally, if any $\mathrm{AFB}$ are found in the same site of sister sections, it limits the possibility of the occurrence of AFB caused by contamination during the staining procedure. And the confirmation that $\mathrm{AFB}$ are in a nerve provides a strong evidence for the diagnosis of leprosy ${ }^{(10.11)}$.

The results shown above reveal that, in active lesions of BT cases, the site where AFB are likely to

The Table. Histopathological location of AFB detected from tissue sections of BT Cases

\begin{tabular}{|c|c|c|c|c|c|c|c|c|c|c|c|c|}
\hline Case $\mathrm{N}_{0}$ & 1 & 2 & 3 & 4 & 5 & 6 & 7 & 8 & 9 & 10 & 11 & 12 \\
\hline \multicolumn{13}{|l|}{ Nerve bundles } \\
\hline unaffected & & - & - & - & & - & & - & - & & & \\
\hline $\begin{array}{l}\text { involved in non-specific inflammation } \\
\text { perineurium }\end{array}$ & & - & & & & & & & & & & \\
\hline parenchyma & & & + & & & & & + & & & & \\
\hline involved in granulomatous reaction & & & & & & & & & & & & \\
\hline segment & & - & - & & + & & - & & & - & & - \\
\hline fragment & & + & - & - & - & & + & + & + & + & + & + \\
\hline remnant & + & - & - & & - & - & - & - & - & - & - & $+r$ \\
\hline fibrosed & & & & & & + & & & & + & & \\
\hline Subepidermal zone & - & - & - & - & - & - & - & - & - & - & - & - \\
\hline \multicolumn{13}{|l|}{ Arrector pili muscle } \\
\hline infiltrated & & - & & & & & - & & & & & + \\
\hline uninfiltrated & & - & - & + & - & & - & - & - & - & & - \\
\hline Macrophages & - & - & - & - & - & - & - & - & - & - & - & - \\
\hline Vessels & - & - & - & - & - & - & - & - & - & - & - & - \\
\hline Others & - & - & - & - & - & - & - & - & - & - & - & - \\
\hline
\end{tabular}




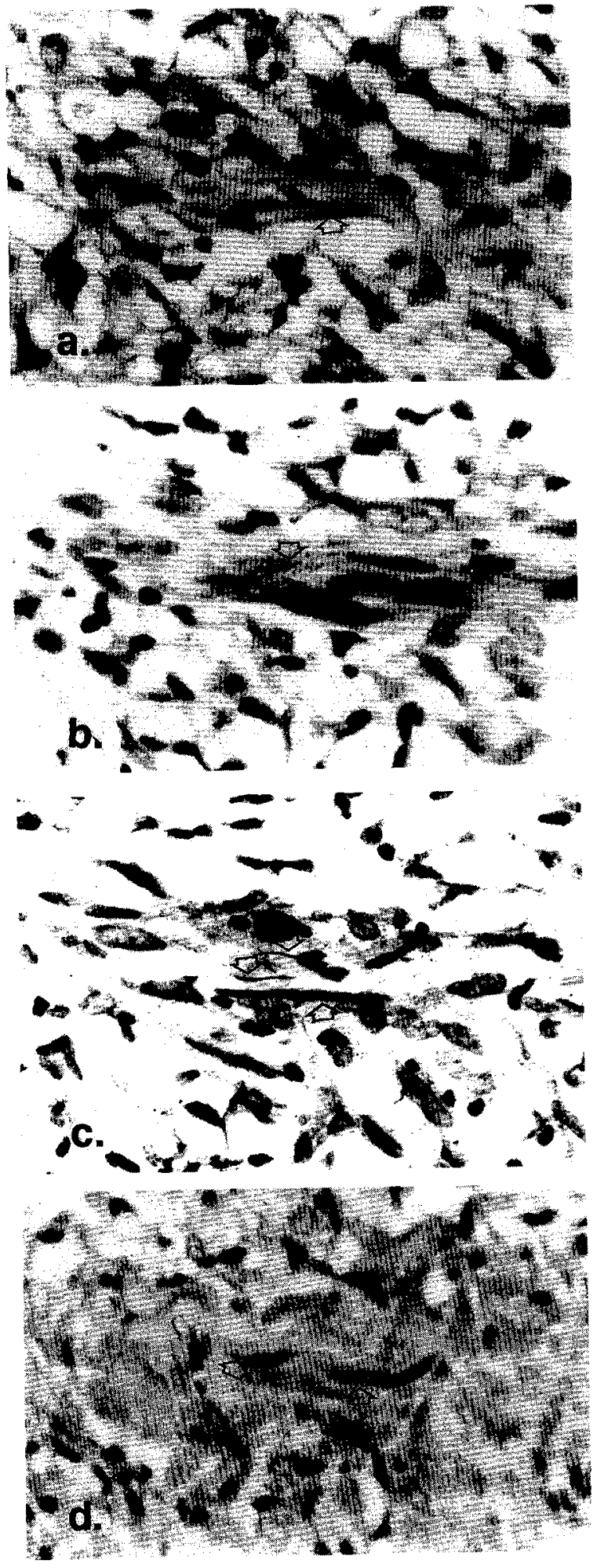

Fig. 1.

four serial sections of skin biopsy taken from case 2 . a. epithelioid cell gramuloma ; no nerve component being confirmed. $\mathrm{H} \& \mathrm{E} ; \mathrm{x} 1000 . \mathrm{b}$. nerve fragment shown by $\mathrm{S}-100$ protein positive staining. S-100 protein ABC technique; x1000. c. some axons with degeneration. Kawatsu's method; $x 1000 . d$. AFB in the nerve fragment. Fite method; $x 1000$. 


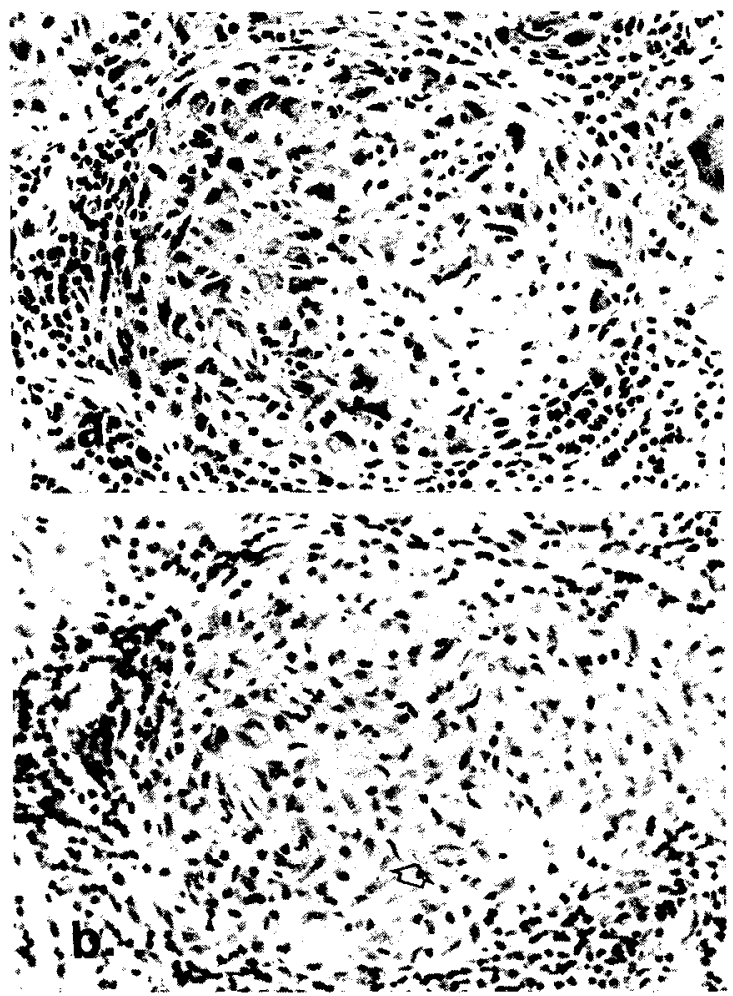

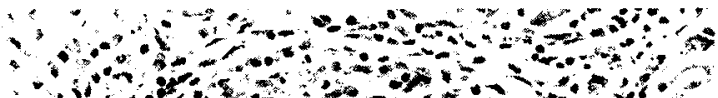
1.

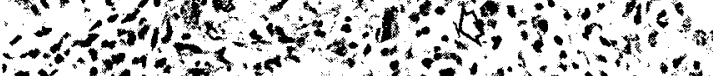

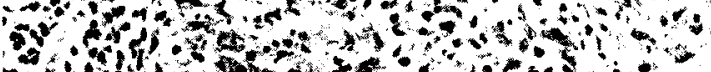

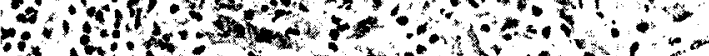

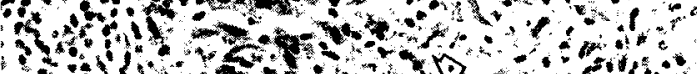

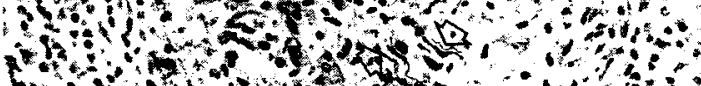
1.0.

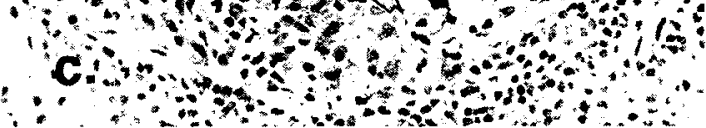

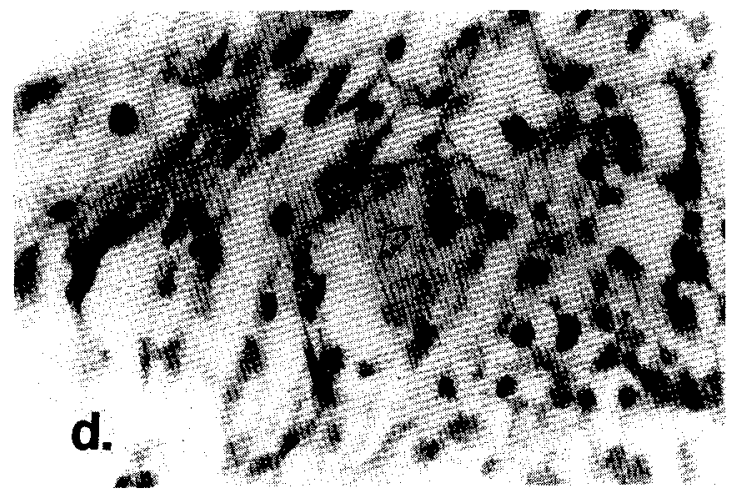

Fig. 2.

four serial sections of skin biopsy taken from case 1. a. epithelioid cell gramuloma ; no remaining nerve being recognized. $H \& E ; x 400$. b. suspected nerve remnant with $\mathrm{S}-100$ protein weak positive staining. S-100 protein $\mathrm{ABC}$ technique ; $x 400$. c. nerve remnant confirmed by the appearance of axons. Kawatsu's method; $\mathrm{x} 400$. d. AFB found in the nerve remnant. Fite method; $\mathrm{x} 1000$. 
be found, was a nerve invaded by epithelioid cell granuloma, especially, the nerve fragment within granuloma and no AFB were detected in unaffected nerve bundles. It contrasts sharply with that, in early lesions, AFB are never observed in a nerve with epithelioid cell infiltration but quite often AFB are detected at a site where there is no cellular reaction ${ }^{(10.11)}$. The difference may be caused by that all biopsies were taken from well established skin lesions of BT cases. If there were any organisms, they would be targeted by cellular reaction.

In general consideration, nerves and arrector pili muscles are the protective sites for M. leprae. The survival of M. leprae in these sites is one of the reasons causing relapse (11) . In this study, AFB existed in nerve and arrector pili muscles, even in nerve remnants, which were almost destroyed by granuloma and also in fibrosed and or hyalinated nerves. This finding suggests that it would be better to consider all BT cases with active lesions as multibacillary cases and put them under the multibacillary regimen recommended by WHO, even though smear-negative, in order to reduce relapse rate.

\section{SUMMARY}

The multi-sections, which were stained by Fite method, of skin biopsies taken from twelve active BT cases were examined under the guidance of special stains for demonstration of nerve components. All cases were AFB positive. Bacilli were found in infiltrated nerves in 11 cases, of which, in 7 cases, bacilli were detected in nerve fragments within epithelioid cell granuloma. And bacilli were seen in arrector pili muscles in 2 cases. No bacilli were detected in other sites.

Since the survival of $\mathrm{M}$. leprae in nerves is one of the reasons causing relapse, this paper suggests that it would be better to treat active BT cases with multibacillary regimen recommended by WHO even though smear-negative.

\section{REFERENCES}

1) WHO Technical Report Series, №.675, 1982.

2) WHO Technical Report Series, №.768, 1988.

3) Pattyn, S.R. et al. : Evaluation of five treatment regimens, using either dapsone monotherapy or several doses of rifampicin in the treatment of paucibacillary leprosy. Lepr. Rev., 61, 151-156(1990).

4) Grugni, A. et al. : Relapses in paucibacillary leprosy after MDT-a clinical study. Int. J. Lepr., 58, 19-24(1989).

5 ) Brakel, W.V. et al.: Relapses after multidrug therapy for leprosy : a preliminary report of 22 cases in West Nepal. Lepr. Rev., 60, 45-50(1989).

6) Katoch, K. et al. : Relapses in paucibacillary patients after treatment with three short-term regimens containing rifampin. Int. J. Lepr., 57, 458-464(1988).

7) Boerrigter, G. et al. : Four-year follow-up results of a WHO recommended multi-drug regimen in paucibacillary leprosy patients in Malawi. Int. J. Lepr., 59, 255-261(1990).

8 ) Ridley, D.S. \& Jopling. W.H. : Classification of leprosy according to immunity, a fivegroup system. Int. J. Lepr., 34, 255-273(1966).

9) Kawatsu, K. : Study on the histopathological stain of nerve fiber, influence of the combination of gelasin and silver in gelatin silver (in Japanese). Jap. J. Med. Photo., 29, 1217 (1991).

10) Ridley, D.S. : Skin biopsy in leprosy. 2nd. ed., Documenta Geigy., Basle(1985) .

11) Ridley, D.S. : Pathology and bacteriology of early lesions in leprosy. Int. J. Lepr., 39, 216 

$-224(1971)$.

12) Meyers, W.M. : Hansen's disease (HD) research: status 1990 . The star., 50 (4), 25 (1991).

\title{
ボーダーライン類結核らい（BT）の組織細菌学的検索
}

\author{
王鉄 生, Khalid I. Butt, 前 田 百 美 \\ 川津 邦 雄, 和 泉 畺 藏 \\ (国立多摩研究所)
}

キーワード：少菌型らい，抗酸菌，連続切片，神経染色

12例の BT 群らいの皮膚生検を行い, 連続切片を 作成した。神経特異染色により標本中の神経の位置 を確認し，それを指標としてFite 法により抗酸菌の 検索を行った。その結果，全例に抗酸菌を認めた。 抗酸菌の存在部位は，立毛筋中に認めたもの 2 例， 細胞浸潤を伴う神経束中に認めたもの11例であった
が, 後者のうち 7 例は肉芽腫中の神経に菌を認めた。 神経中で生き残ったらい菌が, 再燃の原因のひと つであることを考慮すると,今回の結果は, BT 群の らいの場合, 例え塗沫菌検查が陰性であっても, 多 菌型らいとして治療することが望ましいことを示し ている。 